\title{
Determination of Seven Volatile N-Nitrosamines in Fast Food
}

\author{
Mohammad Al-Kaseem ${ }^{1}$, Zaid Al-Assaf ${ }^{1}$, François Karabeet ${ }^{2}$ \\ ${ }^{1}$ Department of Analytical and Food Chemistry, Faculty of Pharmacy, Damascus University, Damascus, Syria; ${ }^{2}$ Department of Che- \\ mistry, Faculty of Science, Damascus University, Damascus, Syria. \\ Email: mkaseem74@gmail.com
}

Received December $13^{\text {th }}, 2013$; revised January $14^{\text {th }}, 2014$; accepted January $29^{\text {th }}, 2014$

Copyright (C) 2014 Mohammad Al-Kaseem et al. This is an open access article distributed under the Creative Commons Attribution License, which permits unrestricted use, distribution, and reproduction in any medium, provided the original work is properly cited. In accordance of the Creative Commons Attribution License all Copyrights (C) 2014 are reserved for SCIRP and the owner of the intellectual property Mohammad Al-Kaseem et al. All Copyright (C) 2014 are guarded by law and by SCIRP as a guardian.

\section{ABSTRACT}

In this study, various fast food samples, including raw meat, cured meat, grilled meat, fried meat, smoked meat and canned meat products, were analyzed for the determination of the seven volatile $\mathrm{N}$-nitrosamines. The samples were treated with an aqueous sodium hydroxide ( $\mathrm{NaOH}$ ) by autoclaving at $121^{\circ} \mathrm{C}$ for 10 min and extracted by liquid-liquid extraction with dichloromethane, and then the nitrosamines were pre-concentrated by using activated silica. Then, gas chromatography coupled with flame ionization detector was used for the separation and determination of the different nitrosamines contained in a real sample. The applied method allowed the determination of nitrosamine compounds at trace levels with limit of detection ranging from 0.077 to $0.18 \mathrm{ppb}$, and quantitation limits were from 0.26 to $0.60 \mathrm{ppb}$ for all nitrosamines. The total concentrations of the seven nitrosamines in the studied meat samples ranged from 2.60 to $13.28 \mu \mathrm{g} / \mathrm{kg}$.

\section{KEYWORDS}

\section{GC-FID; N-Nitrosamines; Fast Food; Meat; Autoclave}

\section{Introduction}

Nitrite is one of the very important additives in the meat production process in terms of desirable color, texture, lipid oxidation, and especially for preventing a toxin formation by Clostridium botulinum. Recent evidence has suggested that the nitrite is bactericidal for gastrointestinal, oral and skin pathogenic bacteria when ingested and mixed with gastric acid. But significant concerns exist because nitrite may react with amines and amino acids to produce $\mathrm{N}$-nitrosamines, which are known to be carcinogenic, mutagenic and teratogenic [1]. These compounds are formed by the reaction of secondary amines with nitrosating agents, such as nitrates or nitrites, which are commonly used in the manufacture of meat products [2]. Investigations carried out at various research centers, and food controlling institutions have shown that many food products are contaminated with nitroso compounds, as the result of various technological processes in which they form in slightly acidic environments by reaction of sodium nitrite and nitrogen oxide with such precursors as proteins, peptides, amino acids and amines present in food [3]. For this reason, the use of these nitrosating agents for curing meat is strictly controlled in some countries [4]. Moreover, some known inhibitors of the nitrosation reaction, such as ascorbic acid, are used in the processing of several foods [5,6]. N-nitrosamines are formed after cooking of meat in a complex process that is influence by a large variety of substances [7]. The main precursors of N-nitrosamines are believed to be formed by reaction of nitrogen oxides (that are generated from nitrites and are also present in wood smoke) with mainly secondary amines present in the meat [8], although they can also occur in the environmental tobacco smoke [9] and may be formed endogenously within the human body [10]. The International Agency for Research on Cancer (IARC) classified N-nitrosodimethylamine (NDMA) and N-nitrosodiethylamine (NDEA) as most carcinogenic to humans, and N-nitrosodi-n-butylamine (NDBA), N-ni- 
trosopiperidine (NPIP) and N-nitrosopyrrolidine (NPYR) as possibly carcinogenic to humans [11]. The determination of nitrosamines in food and water samples has been carried out by different analytical methods [12], including colorimetry [13], capillary electro-chromatography [14], micellar electro-kinetic capillary chromatography [15], gas chromatography with flame ionization detection, nitrogen phosphorous detection, thermal energy detection, nitrogen chemiluminescence detection [16-19], mass spectrometry detection [20-22], high-performance liquid chromatography with thermal energy analyzer, mass spectrometry and fluorescence detection $[23,24]$. The extraction of the nitrosamine from the complex food matrices and the cleanup of the extract have been the critical points of the sample preparation step, and several approaches are documented in the literatures, including distillation (steam or vacuum) [25-27], solvent extraction [28], solid-phase extraction [29], solid-phase micro-extraction (SPME) [30] and supercritical fluid extraction [31].

The purpose of the present study was to measure the content of seven volatile N-nitrosamines in meat products (fast food) in Syria by using the method of sample preparation preformed in our previous work [32], and gas chromatography with flame ionization detector (GC-FID) for the separation and determination of nitrosamines in samples which are collected from fast food restaurants in Damascus and Damascus countryside.

\section{Methods}

\subsection{Samples}

All samples of meat products used in this research were purchased from fast food restaurants (cooked or as provided to consumers) in Damascus and Damascus countryside. Information about the kind of meat and the numbers of each sample was collected and presented in Table 1. The samples were crushed and mix with no addition of the fluid and then stored in $-20^{\circ} \mathrm{C}$ before analysis.

\subsection{Materials}

EPA 521 nitrosamine mix standard was purchased from Supleco (USA), this solution contained seven analytes at $2000 \mu \mathrm{g} / \mathrm{mL}$ of each: N-nitrosodimethylamine (NDMA), N-nitrosomethylethylamine (NMEA), N-nitrosodiethylamine (NDEA), $\mathrm{N}$ nitrosopyrrolidine (NPYR), N-nitrosodin-propylamine (NDPA), N-nitrosopiperidine (NPIP) and N-nitrosodi-n-butylamine (NDBA). For sample preparation, sodium hydroxide, ethanol, octane and dichloromethane (DCM) were purchased from Sigma-Aldrich (USA). All other chemicals (ascorbic acid, anhydrous sodium sulfate and sodium chloride) used in this research were of analytical laboratory grade.

\subsection{Apparatus}

Pyrex tubes $(20 \mathrm{ml})$ with heat-stable Teflon-lined caps were used. Glass column $(30 \mathrm{~cm} \times 1.5 \mathrm{~cm})$. KudernaDanish (KD) concentrator was used for the concentration of organic solvents. Autoclave (Selecta, Spain, 4001757) and gas chromatograph equipped with a flame ionization detector controlled by computer running GC-Solution software (GC-2014, Shimadzu, Japan) and an optimaXLB Capillary Columns $(0.25 \mathrm{~mm}$ i.d. $30 \mathrm{~m}, 0.25 \mu \mathrm{m})$ from (MACHEREY-NAGEL GmbH \& Co) were used. CAMAG UV Lamp dual wavelength, 254/366 nm, $2 \times 8$ watt in combination (Switzerland).

\subsection{Preparation of Nitrosamine Mix Standard}

A series of working standard solutions were prepared by

Table 1. Information about samples collected from fast food restaurants.

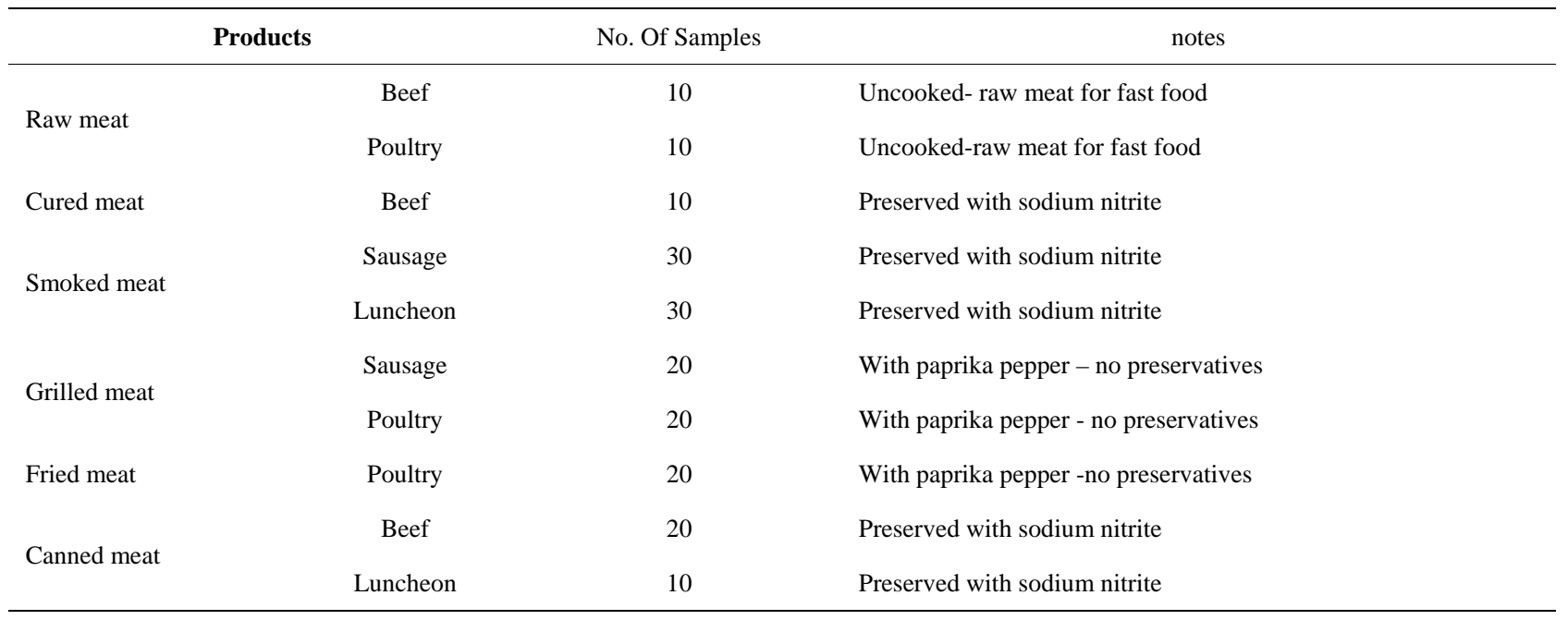


appropriate dilution of the EPA 521 nitrosamine mix with dichloromethane and stored at $-20^{\circ} \mathrm{C}$ before use. From the primary stock solution $2000 \mu \mathrm{g} / \mathrm{mL}$ of each nitrosamine, a 1/200 dilution was done to get $100 \mu \mathrm{g} / \mathrm{mL}$ secondary stock solution of each nitrosamine. Sequentially dilute secondary stock solution was performed to get standards titrating at 4, 10, 50, $100,500,1000 \mu \mathrm{g} / \mathrm{L}$ in by taking the following volumes from secondary stock solution, $40 \mu \mathrm{l}, 100 \mu \mathrm{l}, 500 \mu \mathrm{l}, 1000 \mu \mathrm{l}, 5 \mathrm{~mL}, 10 \mathrm{~mL}$ in series of $100 \mathrm{~mL}$ volumetric flasks respectively, these solution kept in the absence of light.

\subsection{Analytical Conditions}

GC analysis was carried out using GC-2014 gas chromatograph equipped with flame ionization. (GC-FID) (Shimadzo Technologies, Japan). One micro liter of the extracted sample solution was injected into optima-XLB Capillary Column $(30 \mathrm{~m} \times 0.25 \mathrm{~mm}$ I.D. $\times 0.25$ film thickness (df)). For the gas chromatograph separation of $\mathrm{N}$-nitrosamines, the injection port and detector temperature were kept at 250 and $300^{\circ} \mathrm{C}$. The oven program was as follows: $40^{\circ} \mathrm{C}$, held for $3 \mathrm{~min}$; ramp to $100^{\circ} \mathrm{C}$ at $10^{\circ} \mathrm{C} / \mathrm{min}$, held isothermally for $1 \mathrm{~min}$; ramp to $250^{\circ} \mathrm{C}$ at $15^{\circ} \mathrm{C} / \mathrm{min}$, held isothermally at $250^{\circ} \mathrm{C}$ for $2 \mathrm{~min}$. The sample was injected in splitless mode; using an injection volume of $1 \mu \mathrm{l}$. Nitrogen was used as make-up gas. The purity of all gases used was greater than $99.999 \%$. The velocity of the helium carrier was $1 \mathrm{~mL} / \mathrm{min}$.

\subsection{Conditions for Autoclave Treatment}

Conditions for autoclave treatment were adopted as our previous study (Kaseem, Assaf and Karabeet, 2013) [32], half milliliter of the N-nitrosamine Mix standard containing $50 \mu \mathrm{g} / \mathrm{L}$ of each nitrosamine was diluted with 10 $\mathrm{mL}$ of $1 \mathrm{~N}$ aqueous sodium hydroxide and $10 \mathrm{mg}$ of ascorbic acid (Inhibitor of endogenous nitrosation) in 20 $\mathrm{mL}$ Pyrex tubes tightly capped and autoclaved at $121^{\circ} \mathrm{C}$ for $10 \mathrm{~min}$. After being allowed to stand at room temperature, the autoclaved solution was transferred to $50 \mathrm{~mL}$ separatory funnel. The tubes was rinsed twice with $5 \mathrm{~mL}$ of ethanol and then $10 \mathrm{~mL}$ of dichloromethane, and the rinsing solutions and $10 \mathrm{~mL}$ of $10 \%$ aqueous sodium chloride were combined with the original extract in the separatory funnel. After being shaken, the dichloromethane layer was collected, and the water layer was reextracted with $10 \mathrm{ml}$ of dichloromethane. The dichloromethane extracts were combined, dried over anhydrous sodium sulfate and concentrated to approximately 0.5 $\mathrm{mL}$ using $\mathrm{KD}$ concentrator and nitrogen gas flow. The concentrate was loaded onto a silica gel column $(30 \mathrm{~cm} \times$ $1.5 \mathrm{~cm}$ ) (equilibrated with dichloromethane) and the column was eluted with $10 \mathrm{ml}$ of dichloromethane. After the addition of $100 \mu \mathrm{L}$ of octane (to prevent exsiccation of the solvent), the elute was concentrated to $1 \mathrm{~mL}$ using $\mathrm{KD}$ concentrator and nitrogen gas flow and analyzed by GC-FID using $1 \mu \mathrm{L}$ injection volume.

\subsection{Extraction of $\mathrm{N}$-Nitrosamine from Meat}

The method of preparation of meat samples was described in our previous work [32]. Approximately one gram of meat sample was placed in the Pyrex tube into which $10 \mathrm{~mL}$ of sodium hydroxide $1 \mathrm{~N}$ was poured. The tube was capped tightly and autoclaved at $121^{\circ} \mathrm{C}$ for 10 min; dichloromethane extract was obtained by the procedure described for the standard solution in (section 2.6). The individual extracts were analyzed by GC-FID as in the case of the standard solution (Section 2.5).

\subsection{Method Validations}

The matrix effect was studied by comparing the slope of the aqueous standards and standard additions calibration graphs obtained for the sex different fast food samples, namely, raw meat, cured meat, smoked meat, grilled meat, fried meat and canned meat, no statistically differences were observed, and so quantification was carried out by external calibration. Calibration curves were obtained by least squares linear regression analysis for the peak area versus the analyte concentration using six concentration levels in duplicate. The method was validated to demonstrate that it is suitable for its intended purpose by the standard procedure to evaluate adequate validation characteristics [33]. Retention times of selected N-nitrosamines were determined by using standard solutions of each nitrosamine. Figure 1 shows the chromatogram obtained by GC-FID of 50 ppb (part per billion) standard solution of each $\mathrm{N}$-nitrosamine. Figure 2 shows the chromatogram obtained by unspiked meat sample.

\subsubsection{Linear Range, Limit of Quantification (LOQ) and Limit of Detection (LOD)}

A series of working standards at the concentrations of 4 , 10, 50, 100, 500 and $1000 \mu \mathrm{g} / \mathrm{L}$ were prepared and analyzed under the selected chromatographic conditions. The linear equations and the correlation coefficients for the seven N-nitrosamines are shown in Table 2. The limits of quantification with a signal-to-noise ratio of 10 for the seven nitrosamines were from 0.26 to $0.6 \mathrm{ppb}(\mu \mathrm{g} / \mathrm{kg})$ with limits of detection with a signal-to-noise ratio of 3 for the seven nitrosamines were from 0.077 to $0.18 \mathrm{ppb}$.

\subsubsection{Recovery and Precision}

The recovery and precision were conducted by spiking different blank meat samples including, raw meat, cured meat, smoked meat, grilled meat, fried meat, and canned meat. At three spiking levels of $1,5,10 \mu \mathrm{g} / \mathrm{L}$ to the 


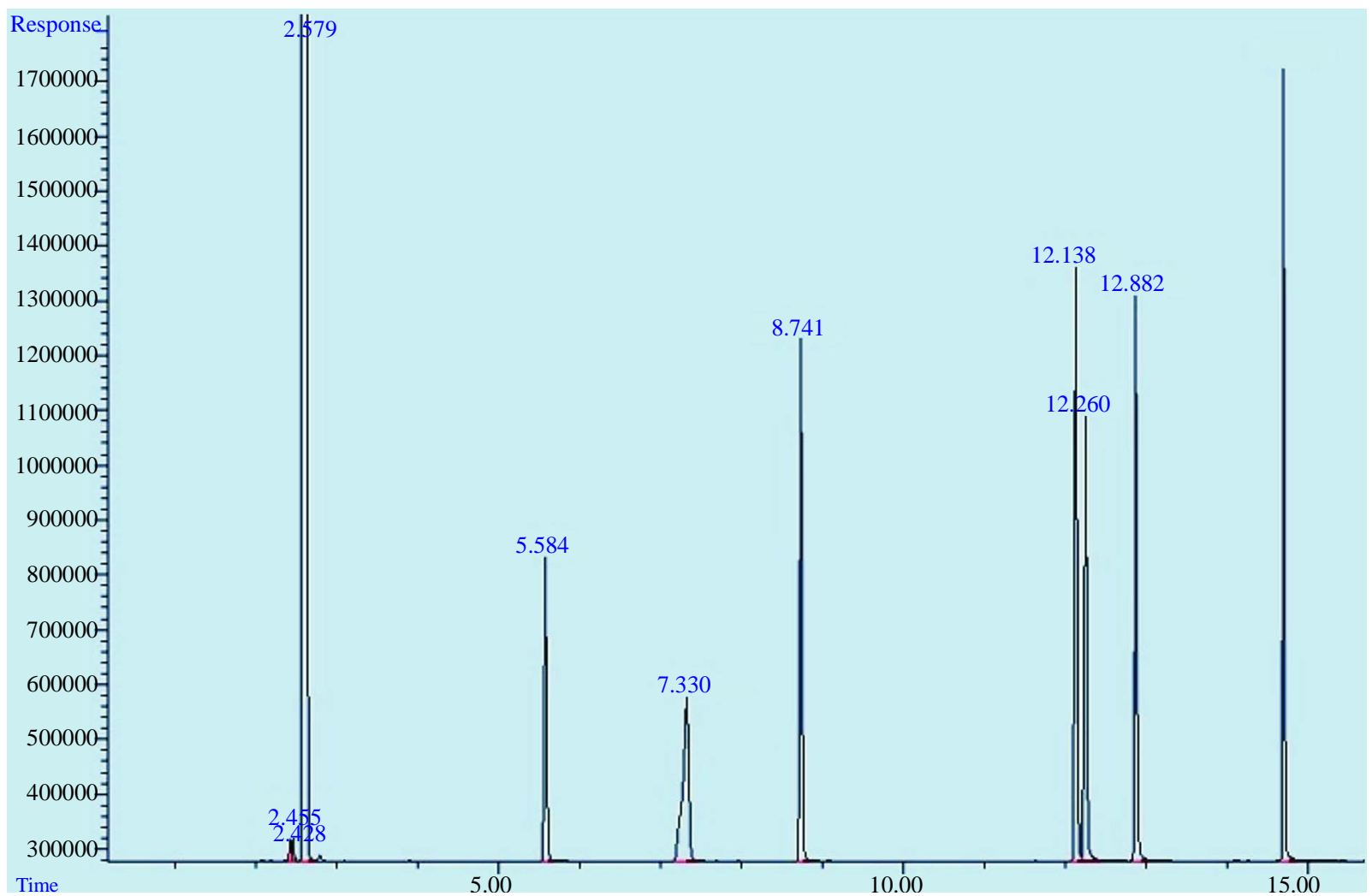

Figure 1. Chromatogram of $50 \mu \mathrm{g} / \mathrm{L}$ of N-nitrosamine Mix (GC-FID).

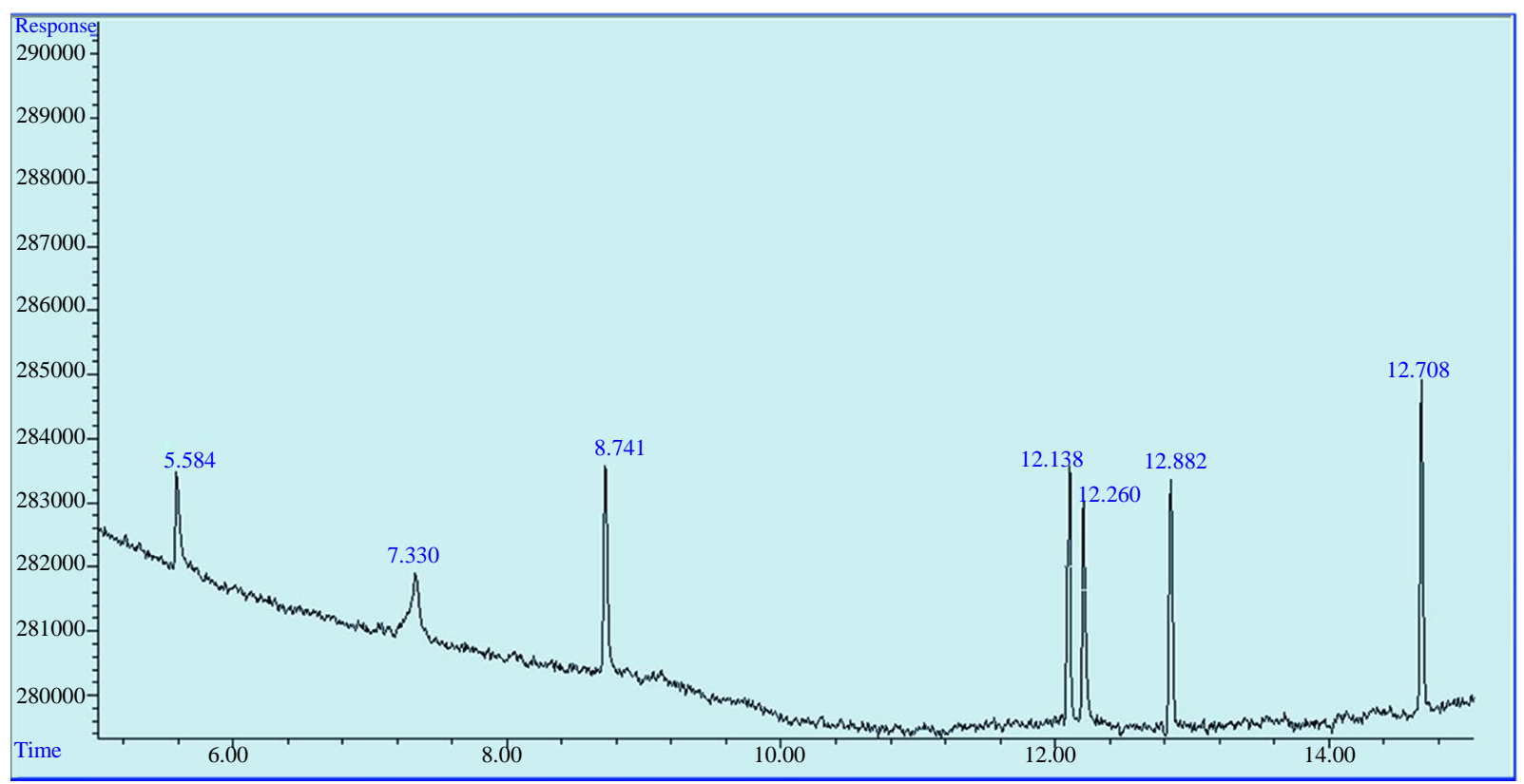

Figure 2. Chromatogram of spiked fried meat sample.

prepared samples, six replicates at each level, the mean recoveries were from $82 \%$ to $105.5 \%$ with the relative standard deviations (RSDs) from $2.8 \%$ to $4.4 \%$.. The results are shown in Table 3 and spiked sample chromatogram is shown in Figure 2.

\subsubsection{Selectivity}

The selectivity of the method was judged from the absence from the interfering peaks (false peaks) at the analyte elution times for blank chromatograms of different unspiked samples after irradiating them to UV light 
Table 2. Linear equations, linear ranges and correlation coefficients of seven volatile nitrosamines.

\begin{tabular}{ccccccc}
\hline N-nitrosamine & RT* GC-FID & Linear equation & Linear range $\mu \mathrm{g} / \mathrm{L}$ & Correlation Coefficients & LOQ $\mu \mathrm{g} / \mathrm{kg}$ & LOD $\mu \mathrm{g} / \mathrm{kg}$ \\
\hline NDMA & 5.617 & $\mathrm{y}=4161.7 \mathrm{x}-9274.8$ & $0.6-500$ & 0.9997 & 0.6 & 0.18 \\
NMEA & 7.344 & $\mathrm{y}=5816.1 \mathrm{x}-14015$ & $0.43-500$ & 0.9994 & 0.43 & 0.13 \\
NDEA & 8.733 & $\mathrm{y}=7095.3 \mathrm{x}-13214$ & $0.33-500$ & 0.9996 & 0.33 & 0.1 \\
NPYR & 12.104 & $\mathrm{y}=8699.3 \mathrm{x}-8839.9$ & $0.26-500$ & 0.9995 & 0.9981 & 0.26 \\
NDPA & 12.224 & $\mathrm{y}=6674.6 \mathrm{x}-3555.2$ & $0.25-500$ & 0.9995 & 0.25 & 0.077 \\
NPIP & 12.853 & $\mathrm{y}=7992.3 \mathrm{x}-141000$ & $0.34-500$ & 0.9998 & 0.34 & 0.105 \\
NDBA & 14.681 & $\mathrm{y}=9805.1 \mathrm{x}-16361$ & $0.30-500$ & 0.309 & 0.093 \\
\hline
\end{tabular}

RT* retention time (minutes), GC-FID; Gas Chromatography-Flame Ionization Detection, LOQ; limit of Quantitation, LOD; Limit of Detection.

Table 3. Results of spiked recoveries for seven volatile nitrosamines in meat samples $(\mathbf{n}=\mathbf{6})$.

\begin{tabular}{|c|c|c|c|c|c|c|c|c|c|c|c|c|c|}
\hline \multirow{2}{*}{ NA } & \multirow{2}{*}{$\begin{array}{l}\text { Spiked Level } \\
(\mu \mathrm{g} / \mathrm{L})\end{array}$} & \multicolumn{2}{|c|}{ Raw meat } & \multicolumn{2}{|c|}{ Cured meat } & \multicolumn{2}{|c|}{ Grilled meat } & \multicolumn{2}{|c|}{ Fried meat } & \multicolumn{2}{|c|}{ Canned meat } & \multicolumn{2}{|c|}{ Smoked meat } \\
\hline & & Recovery & RSD & Recovery & RSD & Recovery & RSD & Recovery & RSD & Recovery & RSD & Recovery & RSD \\
\hline \multirow[t]{2}{*}{ NDMA } & 5 & 91.00 & 2.86 & 84.50 & 3.09 & 87.56 & 3.01 & 87.34 & 2.98 & 83.67 & 3.04 & 82.01 & 4.06 \\
\hline & 10 & 89.10 & 3.23 & 88.08 & 3.12 & 90.98 & 3.11 & 90.88 & 3.18 & 89.00 & 3.30 & 89.90 & 3.98 \\
\hline \multirow{3}{*}{ NMEA } & 1 & 102.00 & 3.87 & 100.89 & 3.13 & 101.78 & 3.12 & 89.07 & 3.17 & 100.09 & 3.34 & 100.00 & 4.40 \\
\hline & 5 & 89.90 & 3.98 & 88.09 & 3.76 & 85.21 & 3.80 & 85.51 & 3.79 & 89.07 & 3.90 & 89.00 & 4.23 \\
\hline & 10 & 89.00 & 2.99 & 90.05 & 4.10 & 90.45 & 3.00 & 91.00 & 2.93 & 88.99 & 3.09 & 89.50 & 3.09 \\
\hline \multirow{2}{*}{ NDEA } & 1 & 105.50 & 4.1 & 91.89 & 4.39 & 102.10 & 4.22 & 102.09 & 4.29 & 104.9 & 4.34 & 91.89 & 4.39 \\
\hline & 10 & 82.01 & 4.06 & 89.89 & 2.89 & 96.06 & 2.90 & 95.90 & 2.91 & 83.04 & 3.03 & 83.03 & 4.34 \\
\hline \multirow{3}{*}{ NPYR } & 1 & 100.00 & 4.40 & 83.03 & 4.34 & 100.90 & 4.40 & 101.01 & 4.35 & 100.90 & 4.40 & 101.01 & 4.27 \\
\hline & 5 & 89.00 & 4.23 & 90.89 & 4.09 & 90.08 & 4.08 & 90.10 & 4.01 & 90.00 & 3.88 & 90.07 & 4.09 \\
\hline & 10 & 89.70 & 3.88 & 88.78 & 4.39 & 90.78 & 4.30 & 91.02 & 4.29 & 90.09 & 4.11 & 89.98 & 4.07 \\
\hline \multirow{3}{*}{ NDPA } & 1 & 101.00 & 3.98 & 95.01 & 4.09 & 101.05 & 4.19 & 100.99 & 4.20 & 101.01 & 4.27 & 99.98 & 4.40 \\
\hline & 5 & 94.00 & 4.38 & 99.08 & 4.39 & 94.09 & 4.28 & 94.80 & 4.32 & 95.00 & 4.40 & 94.77 & 4.38 \\
\hline & 10 & 92.00 & 4.31 & 99.67 & 4.33 & 92.78 & 4.38 & 93.03 & 4.12 & 92.93 & 4.20 & 93.01 & 4.19 \\
\hline \multirow[b]{2}{*}{ NPIP } & 1 & 101.00 & 3.89 & 100.78 & 2.89 & 102.01 & 2.99 & 101.99 & 3.09 & 99.98 & 3.10 & 99.77 & 3.09 \\
\hline & 5 & 90.10 & 3.06 & 91.89 & 2.95 & 90.09 & 2.98 & 91.01 & 3.06 & 90.87 & 3.10 & 91.00 & 3.07 \\
\hline \multirow{3}{*}{ NDBA } & 1 & 89.30 & 3.87 & 89.98 & 4.09 & 90.01 & 4.08 & 89.97 & 3.99 & 90.81 & 4.04 & 89.95 & 4.23 \\
\hline & 5 & 92.60 & 3.56 & 85.34 & 4.31 & 93.00 & 4.34 & 94.00 & 4.40 & 91.05 & 4.38 & 88.99 & 4.39 \\
\hline & 10 & 94.00 & 3.58 & 88.23 & 4.08 & 94.06 & 4.10 & 93.77 & 4.09 & 94.00 & 4.08 & 95.01 & 4.40 \\
\hline
\end{tabular}

NA; nitrosamine, Recovery and RSD are expressed as (\%).

(wavelength 366 nanometer) for three hours to destroy nitrosamines if they are present [34]. The original signals were wrongly positive if the signals from the samples are not remarkably diminished after the irradiation. No matrix compounds existed that might give a false positive signal to the blank samples as shown in Figure 3. 


\section{Results and Discussion}

In this work, the level of seven nitrosamines, namely, NDMA, DNEA, NDPA, DDBA, NMEA, DPYR and NPIP, in 180 samples of most popular meat products in fast food resultants in Syria was determined. Data on nitrosamines level in various samples are given in Table 4. The total concentrations of the seven nitrosamines in the studied meat samples ranged from 2.60 to 13.28 $\mu \mathrm{g} / \mathrm{kg}$. The highest levels of nitrosamines were found in fried and smoked meat. Relatively high level was found in grilled meat. In the opposite the low level of nitrosamine was detected in cured meat and canned meat. Nitrosamines were not detected in raw meat (beef and poultry) and this result might be related to the absence of preservatives (Sodium nitrite) and effect of cooking, which may promote nitrosamine formation. The level of total nitrosamines in canned meat (beef and luncheon) was lower than the level in all other samples including the cured meat (cured beef). The level of total nitrosamines in fried meat (poultry) was very high and exceeds $13 \mu \mathrm{g} / \mathrm{kg}$, the concentration of NDMA exceeds $1 \mu \mathrm{g} / \mathrm{kg}$ in fried and smoked meat, while NPYR and NPIP were detected in all positive samples with high concentrations ranged between 1.12 and $8.40 \mu \mathrm{g} / \mathrm{kg}$ for NPYR, and from 0.25 and $1.65 \mu \mathrm{g} / \mathrm{kg}$ for NPIP. The variations in the levels of total nitrosamines in the tested samples may related to many factors including cooking methods, time and temperature of cooking [12], food additives especially sodium nitrite and to the other ingredients of the meal (paprika pepper) [35]. This can explain the negative results which obtained for 20 samples of raw meat because of the absence of all these factors, while the high level of nitrosamines in fried meat may be related to the

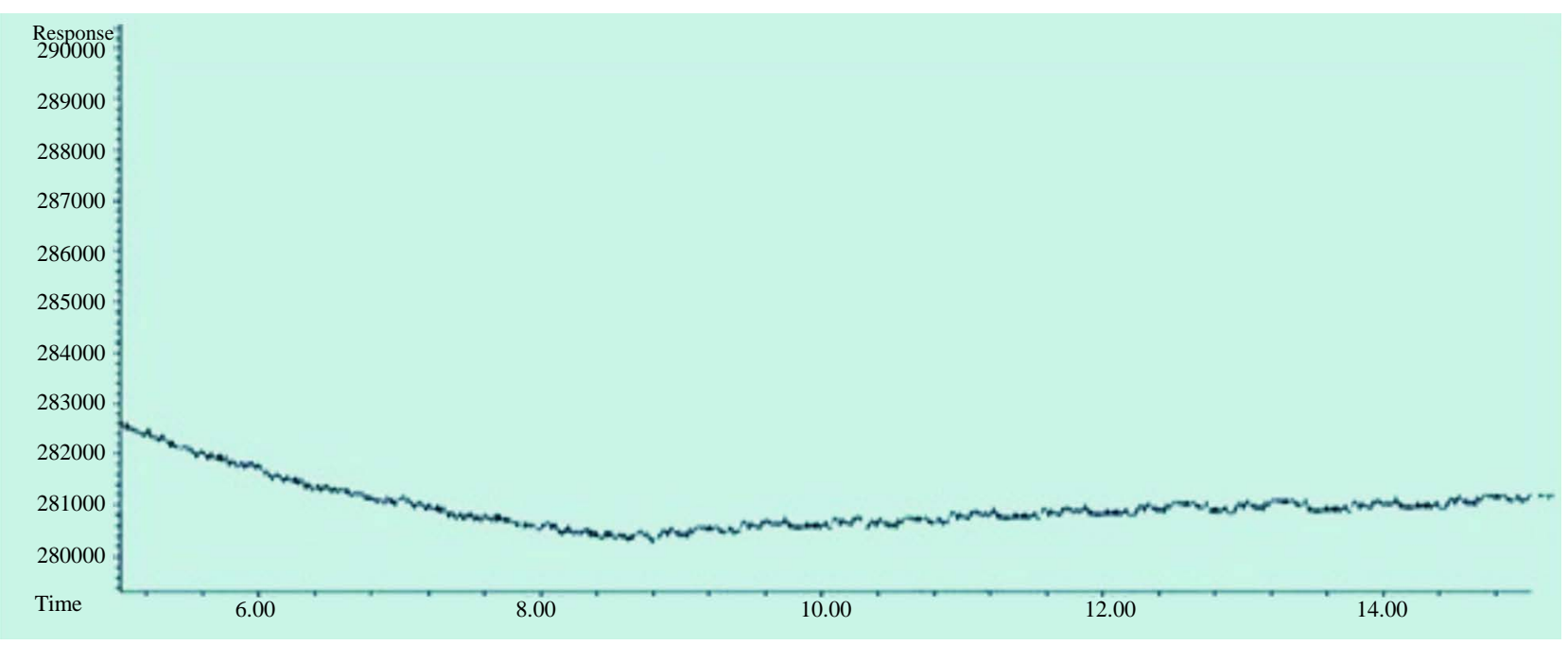

Figure 3. Chromatogram of unspiked fried meat sample after irritation (366 nanometer. 3 hours).

Table 4. Results on nitrosamine results in meat samples.

\begin{tabular}{|c|c|c|c|c|c|c|c|c|c|}
\hline \multirow{2}{*}{\multicolumn{2}{|c|}{ Products }} & \multirow{2}{*}{ No. of Samples } & \multicolumn{6}{|c|}{ Mean concentration $(\mathrm{n}=3$ ) of N-nitrosamine $\mu \mathrm{g} / \mathrm{kg}$} & \multirow{2}{*}{ Sum of seven $\mathrm{N}$-nitrosamine $\mu \mathrm{g} / \mathrm{kg}$} \\
\hline & & & NDMA & NDEA & NDPA & NDBA & NPYR & NPIP & \\
\hline \multirow{2}{*}{ Raw meat } & Beef & 10 & $\mathrm{nd}^{*}$ & $\mathrm{nd}^{*}$ & $\mathrm{nd}^{*}$ & $\mathrm{nd}^{*}$ & nd* & $\mathrm{nd}^{*}$ & $\mathrm{nd}^{*}$ \\
\hline & Poultry & 10 & $\mathrm{nd}^{*}$ & nd* & nd* & $\mathrm{nd}^{*}$ & nd* & nd* & $\mathrm{nd}^{*}$ \\
\hline Cured meat & Beef & 10 & $\mathrm{nd}^{*}$ & nd* & $\mathrm{nd}^{*}$ & $\mathrm{nd}^{*}$ & 3.20 & $\mathrm{nd}^{*}$ & 3.20 \\
\hline \multirow{2}{*}{ Smoked meat } & Sausage & 30 & 1.12 & 0.66 & nd $^{*}$ & $\mathrm{nd}^{*}$ & 4.20 & 1.13 & 7.11 \\
\hline & Luncheon & 30 & 1.05 & 0.54 & 0.28 & 0.31 & 5.12 & 1.65 & 8.95 \\
\hline \multirow{2}{*}{ Grilled meat } & Sausage & 20 & 0.89 & 0.34 & nd $^{*}$ & 0.32 & 2.50 & 0.98 & 5.03 \\
\hline & Poultry & 20 & 0.78 & 0.38 & $\mathrm{nd}^{*}$ & 0.42 & 1.12 & 0.75 & 3.45 \\
\hline Fried meat & Poultry & 20 & 1.16 & 1.23 & 0.81 & 0.45 & 8.40 & 1.23 & 13.28 \\
\hline \multirow{2}{*}{ Canned meat } & Beef & 20 & 0.20 & $\mathrm{nd}^{*}$ & nd* & nd $^{*}$ & 2.10 & 0.23 & 2.92 \\
\hline & Luncheon & 10 & nd* & nd* & nd* & nd* & 2.60 & nd* & 2.60 \\
\hline
\end{tabular}

nd* not detected. 
effect of cooking temperature, which usually exceed $170^{\circ} \mathrm{C}$ [12], and the conventional use of pepper in Syria as spice for fried and grilled meat which may contain precursors for NPYR [36] and this may explain the high levels of NPYR in smoked, grilled and fried samples which contain paprika pepper.

The canned meat usually preserved using sodium nitrite, which is normally added to canned meat such canned meat and luncheon to prevent the formation of toxins produced by Clostridium botulinum, nitrite is also responsible for the development iron reaction with the some meat pigments to produce the desirable red color, and flavor characteristics for these products [37], However, Nitrite is also converted to nitrosating agents that may react with amines and amino acids in meat to produce nitrosamines. The high levels of nitrosamines in sausage could be explain that, sausage is usually made from ground meat, ground fat, salt and spices (sometimes with other ingredients such as herbs) and preserved by sodium nitrite or smoking which serves as nitrosating agents [17]. It was found that NDBA and NDPA were the least observed nitrosamine in meat samples in this study and their concentrations were quite low compared to those of other nitrosamines. These results support earlier studies showing that NDMA and NDEA are commonly found in sausages (Byun et al., 2004; Yurchenko and Molder, 2007) [1,12]. These two nitrosamines were found in the highest concentrations in sausage samples even though these samples were seen to have the lowest sum of Nitrosamines overall. The other meat products containing nitrite and nitrate interestingly had lower NDMA and NDEA values. This might be explained by the differences in their processing conditions and compositions. Statistically when applying (PASW Statistics 18) one way ANOVA test for statistical comparisons between the means of sum of seven nitrosamines in meat samples, there was significant difference $(\mathrm{p}>0.05)$ which may related to negative samples (raw meat), or because that some of tested samples are commonly preserved by nitrite salts (sausages and luncheon) which contributing in nitrosamine formation and the effect of processing (smoking and grilling and frying) in the formation of these carcinogenic compounds in smoked meat.

\section{Conclusion}

In this study, seven nitrosamines were separated and analyzed successfully by using GC-FID after extraction under autoclave conditions. The total concentrations of the seven nitrosamines in the studied meat samples ranged from 2.60 to $13.28 \mu \mathrm{g} / \mathrm{kg}$. The highest levels of nitrosamines were found in fried and smoked meat. Relatively high level was found in grilled meat. In the opposite, the low level of nitrosamine was detected in cured meat and canned meat. The level of total nitrosamines in fried meat (poultry) was very high and exceeded 13 $\mu \mathrm{g} / \mathrm{kg}$, the concentration of NDMA exceeded $1 \mu \mathrm{g} / \mathrm{kg}$ in fried and smoked meat, while NPYR and NPIP were detected in all positive samples with high concentrations ranging between 1.12 and $8.40 \mu \mathrm{g} / \mathrm{kg}$ for NPYR, and from 0.25 to $1.65 \mu \mathrm{g} / \mathrm{kg}$ for NPIP. This study has been important in revealing the high content of nitrosamines in meat-fast food.

\section{REFERENCES}

[1] M. W. Byun, H. J. Ahn, J. H. Kim, J. W. Lee, H. S. Yook and S. B. Han, "Determination of Volatile N-Nitrosamines in Irradiated Fermented Sausage by Gas Chromatography Coupled to a Thermal Energy Analyzer," Journal of Chromatography A, Vol. 1054, No. 1-2, 2004, pp. 403-407.

[2] N. Campillo, P. Viñas, N. C. Martinez and M. H. Córdoba, "Determination of Volatile Nitrosamines in Meat Products by Microwave-Assisted Extraction and Dispersive Liquid-Liquid Micro-Extraction Coupled to Gas Chromatography-Mass Spectrometry,” Journal of Chromatography A, Vol. 1218, No. 14, 2011, pp. 1815-1821. http://dx.doi.org/10.1016/j.chroma.2011.02.010

[3] R. Rywotycki, "Meat Nitrosamine Contamination Level Depending on Animal Breeding Factors," Meat Science, Vol. 65, No. 1, 2003, pp. 669-676. http://dx.doi.org/10.1016/S0309-1740(02)00270-X

[4] K. O. Honikel, "The Use and Control of Nitrate and Nitrite for the Processing of Meat Products," Meat Science, Vol. 78, No. 1-2, 2008, pp. 68-76. http://dx.doi.org/10.1016/j.meatsci.2007.05.030

[5] R. A. Scanlan, "Encyclopedia of Food and Nutrition," Elsevier, Amsterdam, 2003, pp. 4142-4147. http://dx.doi.org/10.1016/B0-12-227055-X/00831-2

[6] H. Robles, "Encyclopedia of Toxicology,” Elsevier, Amsterdam, 2005, pp. 249-250. http://dx.doi.org/10.1016/B0-12-369400-0/00694-3

[7] B. J. Sanchez, E. Ballesteros and M. Gallego, “Automatic Screening Method for the Pre-Concentration and Determination of N-Nitrosamines in Water,” Talanta, Vol. 73, No. 3, 2007, pp. 498-504. http://dx.doi.org/10.1016/j.talanta.2007.04.007

[8] S. Yurchenko and U. Molder, "Volatile N-Nitrosamines in Various Fish Products,” Food Chemistry, Vol. 96, No. 2, 2006, pp. 325-333. http://dx.doi.org/10.1016/j.foodchem.2005.04.009

[9] W. G. Lin, F. Wei, F. N. Gu, X. Dong, L. Gao, T. T. Zhuang, M. B. Yue and J. H. Zhu, "Adsorption of Nitrosamines by Mesoporous Zeolite,” Journal of Colloid and Interface Science, Vol. 348, No. 2, 2010, pp. 621-627. http://dx.doi.org/10.1016/j.jcis.2010.05.012

[10] A. R. Tricker and R. Preussmann, "Carcinogenic N-Nitrosamines in the Diet: Occurrence, Formation, Mechanisms and Carcinogenic Potential," Mutation Research, Vol. 259, No. 3-4, 1991, pp. 277-289.

http://dx.doi.org/10.1016/0165-1218(91)90123-4 
[11] IARC Monographs on the Evaluation of Carcinogenic Risks to Humans, "Monographs Programme Finds Smokeless Tobacco Is Carcinogenic to Humans," International Agency for Research on Cancer, 2004.

[12] S. Yurchenko and U. Molder, "The Occurrence of Volatile N-Nitrosamines in Estonian Meat Products," Food Chemistry, Vol. 100, No. 4, 2007, pp. 1713-1721. http://dx.doi.org/10.1016/j.foodchem.2005.10.017

[13] M. Qiang, X. H. Wei, W. Chao, B. Hua, X. G. Cheng, S. Ning, X. L. Yan and W. J. Bing, "Determination of Ten Volatile Nitrosamines in Cosmetics by Gas Chromatography Tandem Mass Spectrometry," Chinese Journal of Analytical Chemistry, Vol. 39, No. 8, 2011, pp. 12011207. http://dx.doi.org/10.1016/S1872-2040(10)60466-5

[14] M. T. Matyska, J. J. Pesek and L. Yang, "Screening Method for Determining the Presence of N-Nitrosodiethanolamine in Cosmetics by Open-Tubular Capillary Electrochromatography," Journal of Chromatography A, Vol. 887, No. 1-2, 2000, pp. 487-503. http://dx.doi.org/10.1016/S0021-9673(00)00451-9

[15] P. J. S. Filho, M. Valcarcel, A. Rios, K. D. Zanin and E. B. Caramoa, "Determination of Nitrosamines in Preserved Sausages by Solid-Phase Extraction-Micellar ElectroKinetic Chromatography,” Journal of Chromatography A, Vol. 985, No. 1-2, 2003, pp. 503-512. http://dx.doi.org/10.1016/S0021-9673(02)01825-3

[16] J. E. Grebel and H. I. Suffet, "Nitrogen-Phosphorus Detection and Nitrogen Chemiluminescence Detection of Volatile Nitrosamines in Water Matrices: Optimization and Performance Comparison," Journal of Chromatography A, Vol. 1175, No. 1, 2007, pp. 141-144. http://dx.doi.org/10.1016/j.chroma.2007.09.073

[17] M. Z. Ozel, F. Gongus, S. Yagci, J. F. Hamilton and A. C. Lewis, "Determination of Volatile Nitrosamines in Various Meat Products Using Comprehensive Gas Chromatography-Nitrogen Chemiluminescence Detection,” Food and Chemical Toxicology, Vol. 48, No. 11, 2010, pp. 3268-3273. http://dx.doi.org/10.1016/j.fct.2010.08.036

[18] B. Hfiger and R. Niessner, "Determination of N-Nitrosomethylaniline and Methylaniline in the Gas Phase," Microchimica Acta, Vol. 122, No. 1-2, 1996, pp. 35-44. http://dx.doi.org/10.1007/BF01252403

[19] J. A. Incavo and M. A. Schafer, "Simplified Method for the Determination of N-Nitrosamines in Rubber Vulcanizates,” Analytica Chimica Acta, Vol. 557, No. 1-2, 2006, pp. 256-261. http://dx.doi.org/10.1016/j.aca.2005.10.018

[20] D. Tsikas, "Methods of Quantitative Analysis of the Nitric Oxide Metabolites Nitrite and Nitrate in Human Biological Fluids," Free Radical Research, Vol. 39, No. 8, 2005, pp. 797-815. http://dx.doi.org/10.1080/10715760500053651

[21] J. W. Dallinga, D. M. Pachen, A. H. Lousberg, J. A. Van Geel, G. M. Houben, R. W. Stockburgger, J. M. Maanen and J. C. Kleinjans, "Volatile N-Nitrosamines in Gastric Juice of Patients with Various Conditions of the Gastrointestinal Tract Determined by Gas ChromatographyMass Spectrometry and Related to Intragastic $\mathrm{pH}$ and $\mathrm{Ni}-$ trate and Nitrite Levels," Cancer Letters, Vol. 124, No. 2, 1998, pp. 119-125.

http://dx.doi.org/10.1016/S0304-3835(97)00467-9
[22] Y. Xia, J. E. McGuffey, S. Bhattacharyya, B. Sellergren, E. Yilmaz and L. Wang, "Analysis of the Tobacco-Specific Nitrosamine 4-(Methylnitrosamino)-1-(3-Pyridyl)-1Butanol in Urine by Extraction on a Molecularly Imprinted Polymer Column and Liquid Chromatography/ Atmospheric Pressure Ionization Tandem Mass Spectrometry," Analytical Chemistry, Vol. 77, No. 23, 2005, pp. 7639-7645. http://dx.doi.org/10.1021/ac058027u

[23] G. Bellec, M. C. Cauvin, K. L. Calve, Y. Dreano, H. Gouerou, J. F. Menez and F. Berthou, “Analysis of NNitrosamines by High-Performance Liquid Chromatography with Post-Column Photohydrolysis and Colorimetric Detection," Journal of Chromatography A, Vol. 727, No. 1, 1996, pp. 83-92.

http://dx.doi.org/10.1016/0021-9673(95)01073-4

[24] N. V. Komarova and A. A. Velikanov, "Determination of Volatile N-Nitrosamines in Food by High-Performance Liquid Chromatography with Fluorescence Detection," Journal of Analytical Chemistry, Vol. 56, No. 4, 2001, pp. 359-363. http://dx.doi.org/10.1023/A:1016652213062

[25] Association of Official Analytical Chemists, "N-Nitrosamines (Volatile) in Fried Bacon. Mineral Oil Vacuum Distillation-Thermal Energy Analyzer Method,” 15th Edition, No. 982.22, Official Methods of Analysis, 1990.

[26] E. L. Greenfield, W. J. Smith and A. J. Malanovski, "Mineral Oil Vacuum Distillation for Nitrosamines in Fried Bacon, with Thermal Energy Analyser," Journal of the Association Official Analytical Chemists, Vol. 65, No. 6, 1982, pp. 1319-1332.

[27] G. M. Telling, T. A. Bryce and J. J. Althorpe, "Use of Vacuum Distillation and Gas Chromatography-Mass Spectrometry for Determining Low Levels of Volatile Nitrosamines in Meat Products," Journal of Agricultural and Food Chemistry, Vol. 19, No. 5, 1971, pp. 937-940. http://dx.doi.org/10.1021/jf60177a011

[28] J. Nawrocki and P. Andrzejewski, "Nitrosamines and Water,” Journal of Hazardous Materials, Vol. 189, No. 12, 2011, pp. 1-18. http://dx.doi.org/10.1016/j.jhazmat.2011.02.005

[29] S. Raoul, E. Gremaud, H. Biaudet and R. Tureski, "Rapid Solid-Phase Extraction Method for the Detection of Volatile Nitrosoamines in Food," Journal of Agricultural and Food Chemistry, Vol. 45, No. 12, 1997, pp. 4706-4713. http://dx.doi.org/10.1021/jf970232q

[30] S. Ventanas, D. Martín, M. Estévez and J. Ruiz, “Analysis of Volatile Nitrosamines from a Model System Using SPME-DED at Different Temperatures and Times of Extraction," Food Chemistry, Vol. 99, No. 4, 2006, pp. 842850. http://dx.doi.org/10.1016/j.foodchem.2005.08.035

[31] W. Fiddler and J. W. Pensabene, "Supercritical Fluid Extraction of Volatile N-Nitrosamines in Fried Bacon and Its Drippings: Method Comparison,” Journal of AOAC International, Vol. 79, No. 4, 1996, pp. 895-901.

[32] M. Al-kaseem, Z. Assaf and F. Karabeet, "Rapid and Simple Extraction Method for Volatile N-Nitrosamines in Meat Products,” Pharmacology \& Pharmacy, Vol. 4, 2013, pp. 611-618. http://dx.doi.org/10.4236/pp.2013.48087

[33] International Conference on Harmonization, "Validation of Analytical Procedure, Text and Methodology Q2 (R1),” 
IFPMA, Geneva, 2005.

[34] BS ISO 29941, "Condoms-Determination of Nitrosamines Migrating from Natural Rubber Latex Condoms,” International Standards, Section 9, Confirmation of the Detected Nitrosamines, 2010.

[35] D. Kocak, M. Z. Ozel, F. Gogus, J. F. Hamilton and A. C. Lewis, "Determination of Volatile Nitrosamines in Grilled Lamb and Vegetables Using Comprehensive Gas Chromatography-Nitrogen Chemiluminescence Detection," Food Chemistry, Vol. 135, No. 4, 2012, pp. 2215-2220. http://dx.doi.org/10.1016/j.foodchem.2012.07.002

[36] E. T. Huxel, R. A. Scanlan and L. M. Libbey, "Formation of N-Nitrosopyrrolidine from Pyrrolidine Ring Containing Compounds Atelevated Temperatures," Journal of Agricultural and Food Chemistry, Vol. 22, No. 4, 1974, pp. 698-700. http://dx.doi.org/10.1021/jf60194a008

[37] M. L. Nollet and F. Toldra, "Handbook of Processed Meats and Poultry Analysis," In: S. Rath and F. G. R. Reyes, Eds., Nitrosamines, Taylor \& Francis Group, An Informa Business, New York, 2009, p. 684. 